\title{
Yields of millet between shelterbelts in semi-arid northern Nigeria, with a traditional and a scientific method of determining sowing date, and at two levels of organic manuring.
}

L.O.Z. ONYEWOTU1 ${ }^{1}$, C.J. STIGTER ${ }^{2, *}$, E.O. OLADIPO ${ }^{3}$ AND J.J. OWONUBI $^{4}$

1. TTMI-Project, Shelterbelt Research Station of the Forest Research Institute of Nigeria, PMB 3239, Kano, Nigeria

2. TTMI-Project, Department of Environmental Sciences, C.T. de Wit Graduate School of Production Ecology, Wageningen Agricultural University, Duivendaal 2, 6701 AP Wageningen, Netherlands / Department of Geography, Ahmadu Bello University, Zaria, Nigeria

3. TTMI-Project, Department of Geography, Ahmadu Bello University, Zaria, Nigeria

4. Institute for Agricultural Research, Samaru / TTMI-Project, Department of Soil Science, Ahmadu Bello University, Zaria, Nigeria

*Corresponding author (fax: +31-317-482811; e-mail: kees.stigter@users.met. wau.nl)

Received 25 April 1997; accepted 15 March 1998

\begin{abstract}
Eucalyptus camaldulensis shelterbelts positively influenced yields of millet planted close to the belts. Only smaller distances between shelterbelts than used in semi-arid Nigeria, certainly less than $100 \mathrm{~m}$, can fully exploit crop protection from advected hot dry air. Yields in two years with completely different rainfall regimes, for a traditional determination of sowing date, based on the Ramadan, were statistically significantly less (20 - 40\%) than those for a scientific method of determining sowing date, based on Kowal's method. Assistance in on-farm application of proper sowing dates is needed. Millet grown outside the influence of the belts yielded about $50 \%$ less when including both methods of determining the onset of the growing season. Soil moisture availability early in the season and its influence on growth, tillering and grain filling most of all determined yield differences between plots. Substantial yield differences as function of distance from the belts could be explained by soil moisture at sowing and the effects of hot dry turbulent air generated by the belts on crop growth conditions. Compared to the best organic manuring that farmers could afford, half that amount gave yield losses near 35\% in both years, suggesting that manuring is not yet optimum.
\end{abstract}

\section{Résumé}

Des brise-vents d'Eucalyptus camaldulensis ont positivement influencé les rendements du mil semé à proximité. Ce n'est qu'avec des espacements plus petits, entre les brise-vents, que ceux utilisés en zone semi-aride du Nigéria, et certainement inférieurs à $100 \mathrm{~m}$, qu'il est possible d'exploiter pleinement la protection des cultures procurée contre l'advection de l'air sec et chaud. Pendant deux années à régimes pluviométriques complètement différents, les rendements à partir d'une méthode traditionelle de fixation de la date de semis, basée sur l'occurence du mois de Ramadan, étaient significativement inférieurs $(20$ - 40\%) à ceux obtenus avec une fixation scientifique de la date de semis, basée sur la méthode Kowal. Une aide en milieu paysan en vue d'une bonne application des dates de semis appropriées est nécessaire. Le mil a produit à peu près 50\% de moins quand il était cultivé en dehors de la zone d'influence des brise-vents, quelle que soit la méthode utilisée pour déterminer l'approche de la saison culturelle. L'humidité utile du sol au début de saison et ses effets sur la croissance, le tallage et le remplissage des grains ont été les éléments déterminants de la différence de rendement entre les parcelles. Les différences substantielles de rendements observées à l'intérieur des parcelles en fonction de la distance avec les brise-vents sont expliquées par l'humidité du sol au semis et les effets advectifs de l'air turbulent sec et chaud occasionés par les brise-vents sur les conditions de croissance de la culture. Comparativement à la meilleure fertilisation organique que peuvent se permettre les paysans, la moitié de cette quantité a donnée lieu à des pertes de rendement de près de $35 \%$ pendant les deux années, ce qui suggère que la fertilisation par les paysans n'est pas encore optimale. 


\author{
Keywords: \\ Mots clés: \\ advisories, eucalyptus, manuring, millet, Nigeria, shelterbelts, sowing date.
}

avis assistant, brise-vent, date de semis, Eucalyptus, fumier, mil, Nigéria.

\title{
Introduction
}

A major problem of rain-fed agriculture in semi-arid regions with short rainy seasons is how to determine the optimum sowing date for individual crops, a decision tied to a proper definition of onset of the rains (e.g. Ashok Raj, 1979; McCown et al., 1991; Diarra \& Konare, 1994). Onset dates in crop experiments and in more developed commercial growing have been defined using scientific criteria. Some techniques are based on accumulated rainfall totals, while others are based on rainfall/evapotranspiration relations (Ati, 1995; Onyewotu, 1996). Traditional farmers have developed their own definitions, using accumulated experience and/or calendars based on local beliefs.

Another problem of agriculture in these regions is the inadequacy of soil organic matter and other sources of nutrients (McCown et al., 1991; Teme et al., 1996). Soil enrichment with organic/inorganic fertilizers is an absolute necessity for reasonable yields. The quantity of inorganic fertilizers produced in Nigeria has so far not met local demand and only wealthy farmers can afford the high costs which are presently even on the increase. Low external input farmers therefore only convert domestic wastes and animal dung into farm manure.

In semi- arid areas, scattered trees and shelterbelts are very often used to reduce wind erosion and mitigate advection of hot dry air, and not to reduce mechanical damage by wind (Baldy \& Stigter, 1997). This is also the case in northern Nigeria. The purpose of our experiments on multiple shelterbelts is to determine effects of the belts on the yield of pearl millet on-farm as further determined by sowing date method, and level of manure application.

\section{Materials and methods}

The study was conducted at Yambawa $\left(12^{\circ} 27^{\prime} \mathrm{N}\right.$; $\left.08^{\circ} 32^{\prime} \mathrm{E}\right)$, in semi-arid Dambatta Local Government Area of Kano State, Nigeria, under rainfed conditions in 1993 and 1994. The coarse sandy soils are highly deficient in organic matter. Topography shows undulations of stabilized dunes since the area was recently reclaimed from desertification by planting multiple shelterbelts.

The study was carried out in farm plots demarcated between Eucalyptus camaldulensis shelterbelts spaced at distances of between 115 and $300 \mathrm{~m}$ and planted in an east-west direction (Figure 1). At the time of the experiment, the trees had attained a mean height $(\mathrm{H})$ of $12 \mathrm{~m}$. Three blocks (each 108 \&tiems; $60 \mathrm{~m}$ in 1993, and $198 \times 60 \mathrm{~m}$ in 1994, buffer strips of $5 \mathrm{~m}$ excluded) were sub-divided into two equal plots with a $5 \mathrm{~m}$ buffer strip in between (Figure 1). In addition to these researcher-managed fields, farmer-managed fields were included. Two of these, FMC, FMD, were adjacent to the current season's research plots (Site 1 in 1993 and Site 2 in 1994), where the bulk of instruments was positioned. A third field, FME, was located at the opposite site, in a field directly opposite to field FMC. Field FME was in 1994 at the position of field FMC in 1993, to facilitate yield comparisons between the two sites.

In 1994, most instrumentation was moved with the full experiment, including FMC and FMD, to Site 2, where the distance between the belts was almost twice as large (Figure 1). Finally, outside the shelterbelt area two plots of equal size $(42 \times 30 \mathrm{~m}$, excluding $2 \mathrm{~m}$ buffer strip all round), near an instrument reference station, were also farmermanaged (FMA, FMB; Figure 1).

Tree roots were pruned at the $0.25 \mathrm{H}(3 \mathrm{~m})$ distance by digging a narrow trench, which was later closed, one meter deep and $0.5 \mathrm{~m}$ wide, parallel to the belt. The necessity of pruning had been clearly established, and the absence of allelopathic effects, that are often attributed to Eucalyptus, had also been demonstrated (Onyewotu \& Stigter, 1995). The plots were traditionally ox-ploughed, and sown with a local variety of millet (Pennisetum typhoides) in a $1 \times 1 \mathrm{~m}$ grid on ridges running parallel to the belt and $30 \mathrm{~m}$ long. Thinning took place to 5 plants/stand. Ridges are applied for improved managing of water and nutrients (e.g. Sivakumar et al., 1991). 


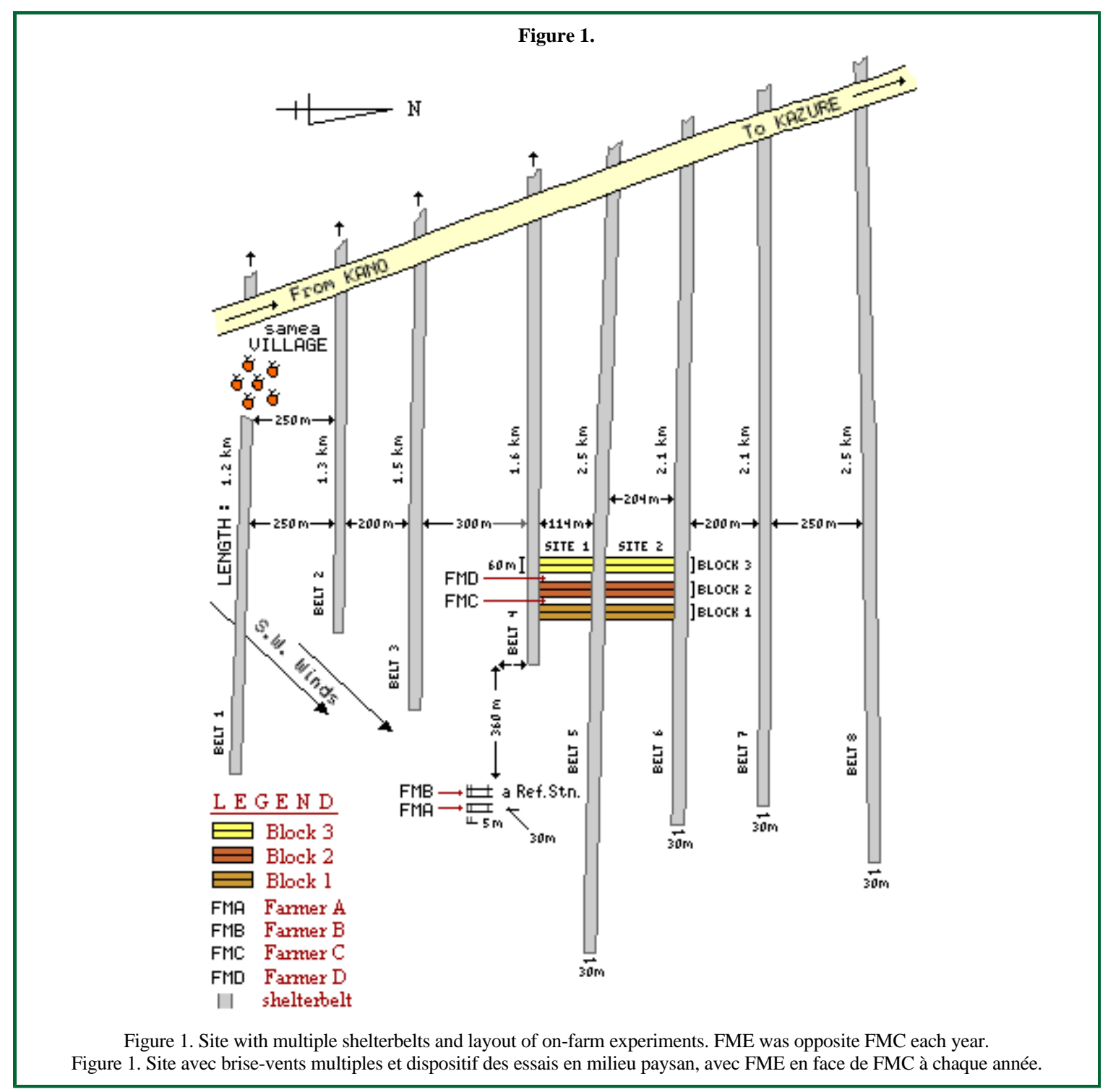

For defining the onset date of annual rains in Nigeria, Kowal \& Knabe (1972) used a combination of accumulated rainfall totals and rainfall/evapotranspiration relations as criteria. This was taken as "the first decade in the season in which the amount of rainfall is equal to or greater than $25 \mathrm{~mm}$, but with a subsequent decade in which the amount of rainfall is at least equal to half the evapotranspiration demand". This "scientific" method of determining sowing date is referred to in this paper as Kowal time (KT).

Traditional farmers in parts of northern Nigeria define the onset of rains as "the day of the first good rain after the muslim fasting period Ramadan, provided it is at least 7 months since the date of the last effective rain of the previous season" (Onyewotu, 1996). This means that if the end of the Ramadan is before the 7-months count (due to the shifting of the lunar calendar which determines the Ramadan), the latter supersedes. Tying the end of Ramadan to the beginning of the cropping season symbolizes the local belief that after fasting the first good rain is blessed by God. This traditional method determining onset date, and therefore sowing date, is referred to in this paper as Ramadan time (RT). Discussions with the participating farmers learned that not all farmers have the same definition of "first good rain" and that such definitions are also depending on the moment in time this rain is observed and the history of scattered rains till that moment (Onyewotu, 1996).

The KT method has the obvious disadvantage that one has to wait for another decade after the first one. The method was improved by Ati (1995) by first determining with the Kowal method an "average onset date" (June 18) from long term average rainfall data and then showing that less false starts of the growing season occurred when using actual annual rainfall data. The date of June 18 apparently is in many cases too early and therefore actual rainfall data were used.

In 1993, the KT and RT sowing dates were 24 and 6 June, and in 1994 they were 9 July and 21 June respectively. We agreed with FMA, FMC and FME to apply our KT, while FMB and FMD applied the RT jointly selected by the farmers. 
Fertilizer treatments included zero (one plot in Block 1), half (one plot in Block 1) and maximal doses (Block 2, two plots in Block 3 and all farmers ploys) of farm-yard manure. The latter as determined by availability and affordability, i.e. one donkey load (about $70 \mathrm{~kg}$ ) for a surface of $25 \mathrm{~m}^{2}$ (about $14 \mathrm{t} \mathrm{ha}^{-1}$ ). Measurements for all treatments included number of tillers and yield at different distances from the belt. For details on other measurements reference is made to Onyewotu (1996).

\section{Results and discussion}

Annual rainfall is highly variable and declining (Ati, 1995), being on average $716 \mathrm{~mm}$ over the period $1962-88$, against $815 \mathrm{~mm}$ over 1962 - 71. Rainfall was only $509 \mathrm{~mm}$ in 1993, but starting in June and very regularly distributed from early July onwards and throughout August, diminishing into September. It was $817 \mathrm{~mm}$ in 1994 , with a very bad distribution: late, because trustable only by mid-July, but becoming torrential early August.

Table 2. Comparative analysis of millet yield $\left(\mathrm{kg} \mathrm{ha}^{-1}\right)$ in plots with traditionally and scientifically determined planting dates during 1993 and 1994 seasons. (Notations as in Table 1).

Tableau 2. Analyse comparative des rendements du mil $\left(\mathrm{kg} \mathrm{ha}^{-1}\right)$ dans des parcelles où la date de semis a été déterminée traditionellement et scientifiquement en 1993 et 1994. (Notations comme au Tableau 1).

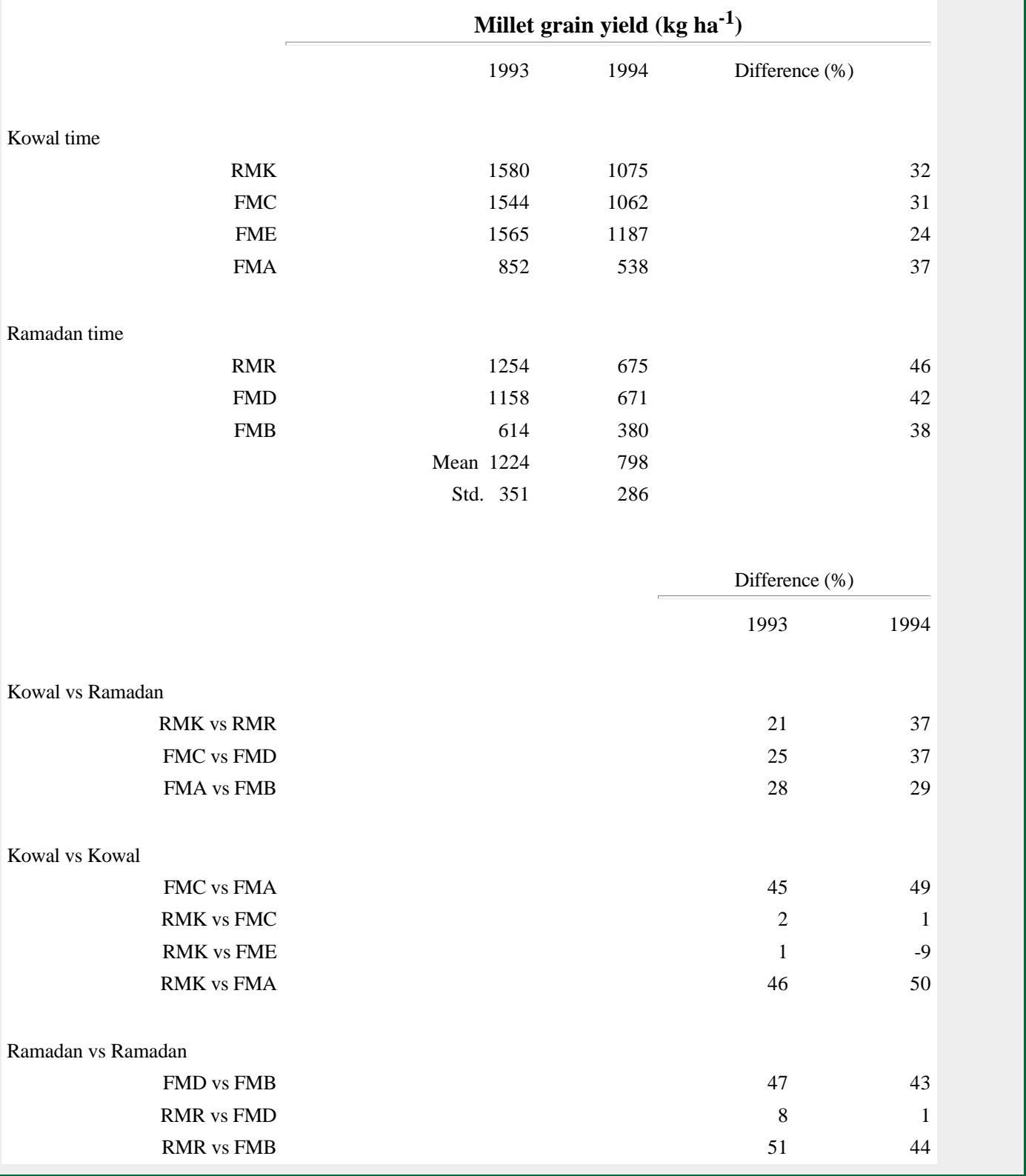


Table $1 \mathrm{~A}$. Millet production characteristics in plots for which sowing date was traditionally (RT method) and scientifically (KT method) determined.

Tableau 1 A. Caractéristiques de la production du mil des parcelles pour lesquelles la date de semis a été determinée traditionellement (méthode RT) et scientifiquement (méthode KT).

\section{A. Inside shelterbelt}

\begin{tabular}{|c|c|c|c|c|c|c|c|c|c|c|}
\hline \multirow[t]{2}{*}{ Site 1} & \multicolumn{10}{|c|}{ Distance from belt (multiples of belt height) } \\
\hline & 1 & 1.5 & 2 & 4 & 6 & 7 & 8 & 8.5 & Mean & Std \\
\hline \multicolumn{11}{|c|}{$1993(\mathrm{RT})$} \\
\hline RMR a & 9 & 9 & 10 & 10 & 7 & 10 & 9 & 6 & 8.8 & 1.4 \\
\hline RMR b & 2.0 & 3.6 & 5.8 & 8.0 & 1.9 & 4.7 & 2.2 & 1.3 & 3.7 & 2.2 \\
\hline RMR c & 0.07 & 0.12 & 0.19 & 0.27 & 0.06 & 0.16 & 0.07 & 0.05 & 0.12 & 0.1 \\
\hline FMD b & 2.1 & 3.7 & 6.0 & 7.8 & 1.9 & 4.8 & 2.1 & 1.4 & 3.7 & 2.1 \\
\hline \multicolumn{11}{|c|}{$1993(\mathrm{KT})$} \\
\hline RMX a & 11 & 12 & 12 & 12 & 10 & 12 & 12 & 8 & 11.1 & 1.4 \\
\hline RMX b & 2.8 & 4.3 & 6.8 & 9.5 & 2.7 & 5.5 & 3.6 & 2.0 & 4.7 & 2.4 \\
\hline RMX c & 0.09 & 0.14 & 0.23 & 0.32 & 0.09 & 0.18 & 0.12 & 0.07 & 0.16 & 0.1 \\
\hline FMC b & 2.8 & 4.4 & 6.8 & 9.2 & 2.4 & 5.4 & 3.6 & 1.7 & 4.5 & 2.3 \\
\hline \multirow[t]{2}{*}{ Site 2} & \multicolumn{10}{|c|}{ Distance from belt (multiples of belt height) } \\
\hline & 1.5 & 3 & 5 & 7.5 & 9.5 & 12 & 14 & 15.5 & Mean & Std \\
\hline \multicolumn{11}{|c|}{$1993(\mathrm{KT})$} \\
\hline FME b & 4.2 & 8.5 & 6.0 & 2.7 & 2.7 & 2.7 & 2.8 & 2.8 & 4.1 & 2.0 \\
\hline \multirow[t]{2}{*}{ Site 2} & \multicolumn{10}{|c|}{ Distance from belt (multiples of belt height) } \\
\hline & 1.5 & 3 & 5 & 7.5 & 9.5 & 12 & 14 & 15.5 & Mean & Std \\
\hline \multicolumn{11}{|c|}{$1994(\mathrm{RT})$} \\
\hline RMR a & 10 & 10 & 10 & 7 & 7 & 7 & 10 & 9 & 8.8 & 1.4 \\
\hline RMR b & 2.0 & 2.5 & 3.1 & 1.8 & 1.3 & 1.4 & 2.0 & 2.1 & 2.0 & 0.5 \\
\hline RMR c & 0.07 & 0.08 & 0.10 & 0.06 & 0.04 & 0.05 & 0.07 & 0.07 & 0.07 & 0.0 \\
\hline FMD b & 2.1 & 3.0 & 2.6 & 1.8 & 1.2 & 1.4 & 2.0 & 2.0 & 2.0 & 0.5 \\
\hline \multicolumn{11}{|c|}{$1994(\mathrm{KT})$} \\
\hline RMX a & 12 & 12 & 12 & 9 & 8 & 8 & 12 & 12 & 10.6 & 1.8 \\
\hline RMX b & 3.0 & 4.1 & 3.8 & 2.8 & 2.5 & 2.5 & 3.5 & 3.6 & 3.2 & 0.6 \\
\hline RMX c & 0.10 & 0.14 & 0.13 & 0.09 & 0.08 & 0.08 & 0.12 & 0.12 & 0.1 & 0.0 \\
\hline $\mathrm{FMC} \mathrm{b}$ & 4.0 & 4.8 & 3.8 & 2.6 & 2.4 & 2.4 & 2.8 & 2.7 & 3.2 & 0.8 \\
\hline \multirow[t]{2}{*}{ Site 1} & \multicolumn{10}{|c|}{ Distance from belt (multiples of belt height) } \\
\hline & 1 & 1.5 & 2 & 4 & 6 & 7 & 8 & 8.5 & Mean & Std \\
\hline \multicolumn{11}{|c|}{$1994(\mathrm{KT})$} \\
\hline FME b & 4.3 & 4.5 & 4.7 & 4.9 & 1.4 & 3.1 & 2.8 & 2.8 & 3.6 & 1.1 \\
\hline
\end{tabular}

In general, yield in 1994 was significantly lower than that in $1993(\mathrm{t}=9.29, P<0.01)$ (Tables $\underline{1}$ and $\underline{2})$, due to these characteristics of the rainy season. The results of these tables show no systematic yield differences between participating farmers and researchers, for the same sowing dates.

The patterns of replicate grain yield averages as function of distance from the southern belts were independent of sowing time (Table 1 ). In a t-test for paired comparisons, RT yield data were statistically significantly lower than those from KT sowing dates in 1993 and $1994(\mathrm{t}=8.62, P<0.01$ and $\mathrm{t}=10.89, P<0.01$, respectively; see also Table 2 ). As the number of stands per row is virtually constant, this applies to yield per row as well as to yield per stand. 
Table 1 B. Millet production characteristics in plots for which sowing date was traditionally (RT method) and scientifically (KT method) determined.

Tableau 1 B. Caractéristiques de la production du mil des parcelles pour lesquelles la date de semis a été determinée traditionellement (méthode RT) et scientifiquement (méthode KT).

\section{B. Outside shelterbelt}

\begin{tabular}{|c|c|c|c|c|c|c|}
\hline \multirow[t]{2}{*}{ Site 1} & \multicolumn{6}{|l|}{ Distance from belt (m) } \\
\hline & 12 & 18 & & 24 & Mean & Std \\
\hline \multicolumn{7}{|c|}{1993 (RT) } \\
\hline FMB a & 7 & & 7 & 7 & 7 & 0 \\
\hline FMB b & 1.9 & & 1.9 & 1.9 & 1.9 & 0 \\
\hline FMB c & 0.06 & & 0.06 & 0.06 & 0.06 & 0 \\
\hline \multicolumn{7}{|c|}{$1993(\mathrm{KT})$} \\
\hline FMA a & 10 & & 10 & 10 & 10 & 0 \\
\hline FMA b & 2.5 & & 2.7 & 2.7 & 2.6 & 0.1 \\
\hline FMA c & 0.08 & & 0.09 & 0.09 & 0.09 & 0 \\
\hline \multirow[t]{2}{*}{ Site 2} & \multicolumn{6}{|l|}{ Distance from belt (m) } \\
\hline & 12 & 18 & & 24 & Mean & Std \\
\hline \multicolumn{7}{|c|}{1994 (RT) } \\
\hline FMB a & 7 & & 7 & 7 & 7 & 0 \\
\hline FMB b & 1.1 & & 1.2 & 1.0 & 1.1 & 0.1 \\
\hline FMB c & 0.04 & & 0.04 & 0.03 & 0.04 & 0 \\
\hline \multicolumn{7}{|c|}{$1994(\mathrm{KT})$} \\
\hline FMA a & 9 & & 9 & 8 & 8.7 & 0.5 \\
\hline FMA b & 1.7 & & 1.6 & 1.5 & 1.6 & 0.1 \\
\hline FMA c & 0.06 & & 0.05 & 0.03 & 0.05 & 0 \\
\hline \multicolumn{7}{|c|}{$\begin{array}{ll}\text { RMK }=\text { Kowal time plot managed by the research team } & \begin{array}{l}\mathrm{a}=\text { Average no. of tillers } / \mathrm{stand} \\
\mathrm{RMR}=\text { Ramadan time plot managed by the research team } \\
\mathrm{b}=\text { Average yield } / \mathrm{row}(\mathrm{kg}) \\
\mathrm{FMA}=\text { Kowal time plot managed by Farmer A }\end{array} \\
\text { FMB = Ramadan time plot managed by Farmer B } & \\
\text { FMC }=\text { Kowal time plot managed by Farmer C } & \\
\text { FMD }=\text { Ramadan time plot managed by Farmer D } & \\
\text { FME }=\text { Kowal time plot managed by Farmer E } & \end{array}$} \\
\hline
\end{tabular}

This result confirmed a simpler measuring accuracy approach on percentage differences in total yield, in which the error limits did far from overlap. The overall differences in yield between the two sowing dates must be mainly due to soil water availability, particularly during the seedling stage, because other crucial factors only differed slightly when integrated between the belts (Onyewotu, 1996). Total soil water storage in the top $30 \mathrm{~cm}$ of soil near ridges with millet at RT sowing was lower, $7.5 \pm 0.5 \mathrm{~mm}$ in 1993 and $11.9 \pm 1.4 \mathrm{~mm}$ in 1994, compared to $9.5 \pm 0.8 \mathrm{~mm}$ and $17.4 \pm 1.6 \mathrm{~mm}$ at KT sowing correspondingly, all distances from the belt averaged. Three weeks later this had become $12.9 \pm 0.6 \mathrm{~mm}$ in 1993 and $17.0 \pm 1.5 \mathrm{~mm}$ in 1994 for the RT plot compared to $18.2 \pm 1.1 \mathrm{~mm}$ and $27.9 \pm$ $1.5 \mathrm{~mm}$ for the KT plot.

Tillering is an important production characteristic of millet. The observed moisture differences resulted in statistically significant reductions in the number of tillers per stand $(\mathrm{t}=6.52, P<0.01$ and $\mathrm{t}=9.47, P<0.01$, in 1993 and 1994, respectively). In 1994 this was worsened by less grains/tiller for RT sowings, as a comparison of tillers and total yields reveals (RMR and RMK in Table 1; details in Onyewotu, 1996). Therefore, to increase yield farmers should be advised to use KT sowing dates.

To get such scientific sowing dates applied, on- line (e.g. radio) weather advisories (Stigter \& Weiss, 1986; Mungai et al., 1996) on such dates may be developed (e.g. Konare, 1990). However, because tropical rains are very location specific, there is an even larger need for scientific methodologies with which farmers themselves can determine a sowing date for the ongoing season on-farm (e.g. Stewart, 1991). 
Perpendicular to the belts, areas of lower yield corresponded with areas of lower initial soil moisture (Figure 2) and this effect will have been stronger nearer the surface. Wind speeds were low, but there was somewhat higher wind speed in areas of lower yield (Onyewotu, 1996). Although shelterbelts are known to increase crop yield by reducing wind speed, and consequently improving the microclimate of the protected zone (e.g McNaughton, 1988), these differences do not fully explain all of the surprisingly huge sudden yield gradients occurring with distance to the belts in Table 1 . Between 1 and $1.5 \mathrm{H}$ shade is causing only a small effect (Onyewotu et al., 1994), while fertility effects were negligible (Onyewotu, 1996).
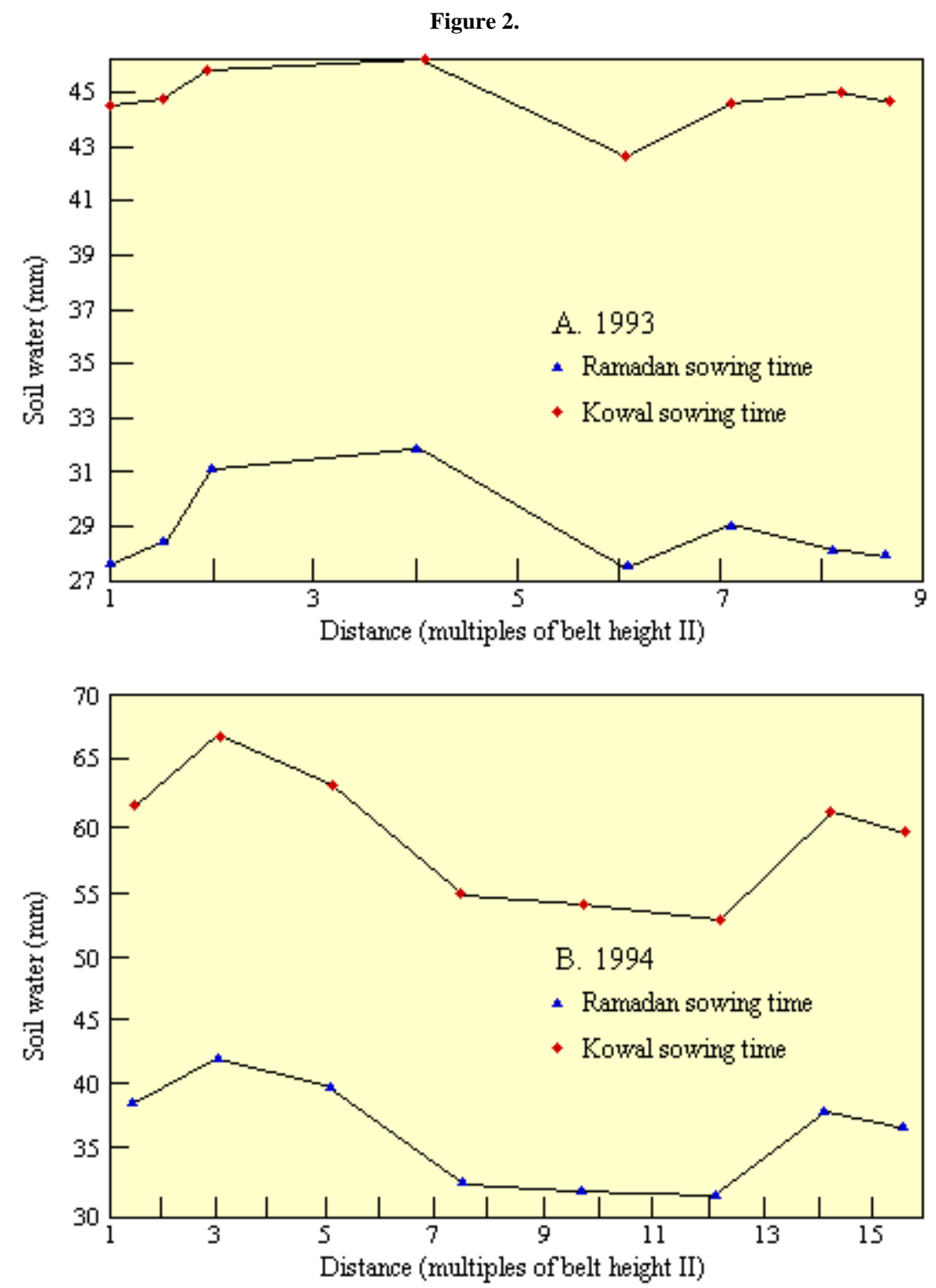

Figure 2. Soil water storage (the sum of four weekly observations) in a $1 \mathrm{~m}$ profile near ridges without millet in the pre- and immediate post-sowing period for RT sowing (lower data) and KT sowing (upper data) in 1993 (A) and 1994 (B).

Figure 2. Réserves en eau du sol (la somme de quatre observations hebdomadaires) à un profil de $1 \mathrm{~m}$ près des billons sans mil à la période juste avant et après les semis pour les semis RT (données inférieures) et KT (données supérieures) en 1993 (A) et 1994 (B).

The present authors have forwarded the hypothesis that the review work of McNaughton (1988) holds the key to these yield gradients. However, it does apply here to advective conditions in the tropics, not to belts planted for protection from mechanical damage by wind. In the area between the parts of land that are actually protected by the belts, very high evaporative demands occur. This is caused by high temperatures of the dry advected air that comes down over the belt, combined with high turbulence induced by the shelterbelt. The resulting aggressive microclimate has adversely influenced the physiological processes of millet. Already rather close to the belts this has offset any gains in grain yield observed closer to the belts (Onyewotu, 1996). This reduced minimum yield between the belts (Table 1, Protected) to values similar to or slightly higher than those obtained outside the influence of the belts (Table $\underline{1}$, Unprotected). 
The wider distance between the belts in 1994, at Site 2 (Figure 1), implied that the extent of the unprotected area, with lower yield, was larger. Millet grown outside the influence of the belts yielded on average 48\% (1993) and $47 \%$ (1994) less when including both methods of determining the onset of the growing season (yields of FMA and FMB compared to those from the same sowing dates between the belts, Table 2).

Only smaller distances than used in northern Nigeria, and certainly less than $100 \mathrm{~m}$ (about $8 \mathrm{H}$ ) between these multiple shelterbelts, can fully exploit the crop protection from advected dry air in semi-arid regions. Planting belts perpendicular to the prevailing winds in the rainy season and making them $15 \mathrm{~m}$ instead of $30 \mathrm{~m}$ wide will occupy less land for virtually the same protection.

Results of chemical analyses showed that the nutrient status of soil receiving full manure and of the manure itself were rather similar for each season. Compared to the maximum available and affordable, for half that amount (i.e. 7 $\mathrm{t} \mathrm{ha}^{-1}$ ) yield was 35\% lower in both years (Table $\underline{3}$ ). This suggests that actual maximum manuring is not yet optimum. Plots that received no manure recorded no grain yield at all, so there are no effects of belts for this condition either.

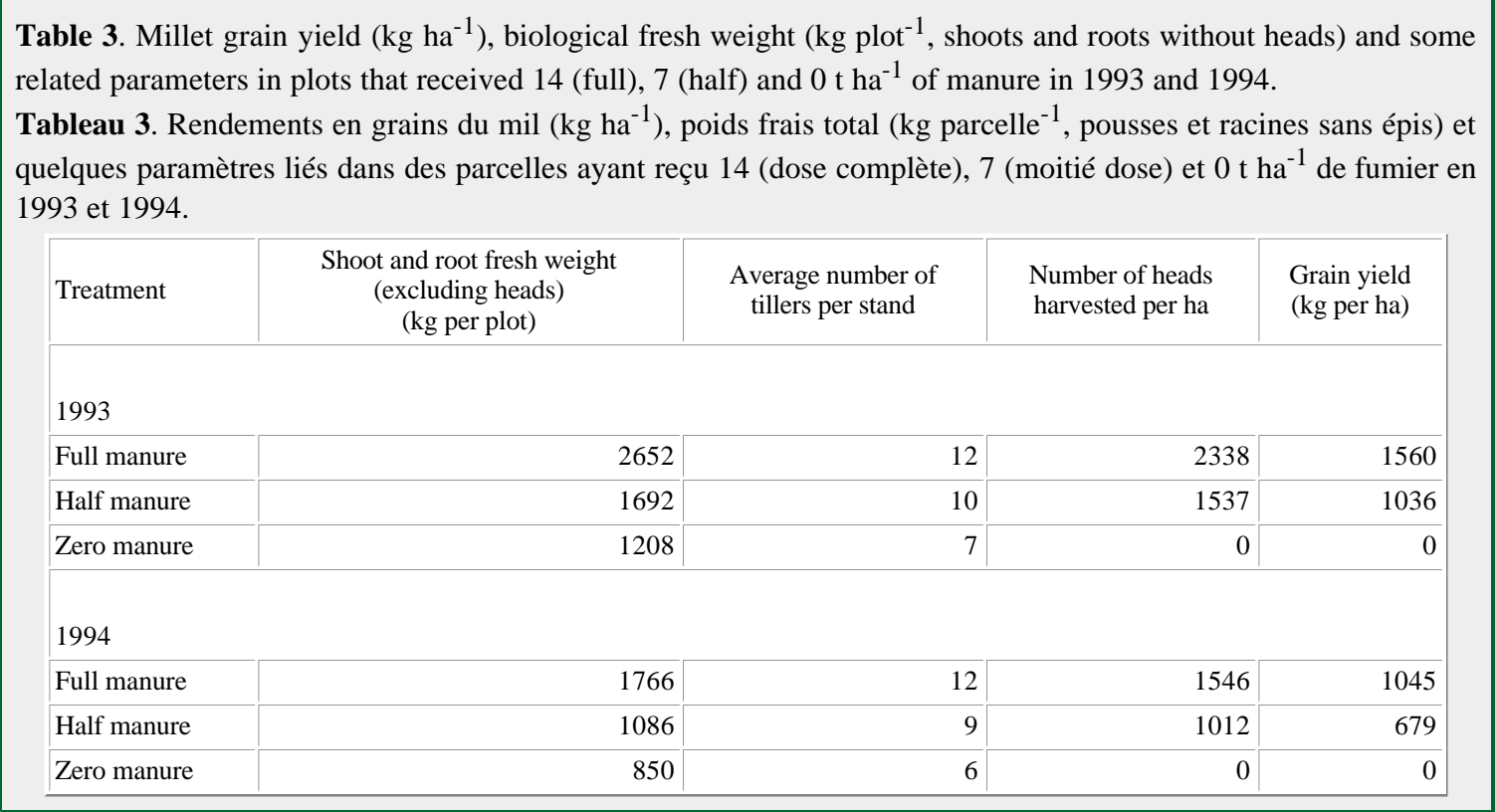

Farmers in the region do not like the shelterbelts, because they occupy much of their land without compensation and they are not allowed to manage the belts themselves (Abdullahi, 1995). No benefits are coming from the present belts other than limited yield increases, close to the belts, when pruned. The farmers interpreted the competition of the trees as an allelopathic effect. The necessary closer spacing would only become acceptable to the farmers with less wide belts perpendicular to the wind and with additional benefits obtained from the trees. Even in that case, parkland agroforestry systems, popularly known in Nigeria as scattered farm-tree plots, of sufficient density, between the present belts (of diminished width) or instead of belts, may well be better alternatives. Participatory on-farm research into the latter systems is highly recommended (Onyewotu, 1996).

Substantial yield increases may be obtained using a scientific determination of sowing date instead of the traditional one, because of the better soil moisture availability early in the season. Assistance in on-farm application of such a sowing date is therefore needed. The local low external input farmers should also be encouraged to apply more farm-yard manure as long as in most cases the additional yield is worth more than the added manure. Manure application seems a key factor for the success of shelterbelts once the latter are appropriately spaced.

\section{References}

Abdullahi, Y.M., 1995.

The socio-economic effects of the Yambawa multiple shelterbelt project near Kano, Nigeria.

MSc-Thesis, Ahmadu Bello University, Department of Geography, Zaria, 97 pp. 
Ashok Raj, P.C., 1979.

Onset of effective monsoon and critical dry spells.

Water Technology Centre, Indian Council for Agricultural Research, New Delhi, 227 pp.

Ati, O.F., 1995.

A comparison of methods to detect the onset of the growing season and its trends for some stations in the Sudan Savanna of Northern Nigeria.

MSc-Thesis, Ahmadu Bello University, Department of Geography, Zaria, $113 \mathrm{pp}$.

Baldy, C. \& C.J. Stigter, 1997.

Agrometeorology of multiple cropping in warm regions.

Science Publ., Enfield (USA) and Oxford \& IBH Publ.Co., New Delhi, 237 pp. [French edition: INRA, Paris, 1993, 246 pp.]

Diarra, B. \& K. Konare, 1994.

Réduction de l'impact du climat sur le calendrier agricole au Sahel.

In: F.N. Reyniers \& L. Netoyo (Eds.), Bilan Hydrique Agricole et Secheresse en Afrique Tropicale. John Libbey, Paris, pp. $31-49$.

Konare, K., 1990.

Meteorological assistance in the Sahelian region: requirements and benefits.

In: Economic and social benefits of meteorological and hydrological services. WMO - No 733, World

Meteorological Organization, Geneva, pp. 144-155.

Kowal, J.M. \& D.T. Knabe, 1972.

An agroclimatological atlas of the northern states of Nigeria with explanatory notes.

Ahmadu Bello University Press, Zaria, pp. 11-25.

McCown, R.L., B.M. Wafula, L. Mohammed, J.G. Ryan \& J.N.G. Hargreaves, 1991.

Assessing the value of a seasonal rainfall predictor to agronomic decisions: the case of response farming in Kenya.

In: R.C. Muchow \& J.A. Bellamy (Eds.), Climatic Risk in Crop Production: Models and Management for the Semi-Arid Tropics and Subtropics. CAB International, Wallingford, pp. 383-409.

McNaughton, K.G., 1988.

Effects of windbreaks on turbulent transport and microclimate.

Agriculture, Ecosystems and Environment 22/23: 17-39.

Mungai, D.N., C.J. Stigter, J.K. Ng'ang'a \& C.L. Coulson, 1996.

New approach in research education to solve problems of dryland farming in Africa.

Arid Soil Research and Rehabilitation 10: 169-177.

Onyewotu, L.O.Z., 1996.

The effects of multiple shelterbelts on microclimate and agricultural use of a desertified semi-arid environment near Kano, Nigeria.

PhD-Thesis, Ahmadu Bello University, Department of Geography, Zaria, Nigeria, 467 pp.

Onyewotu, L.O.Z. \& C.J. Stigter, 1995.

Eucalyptus - its reputation and its roots: millet and a eucalyptus shelterbelt in northern Nigeria. Agroforestry Today 7: 7-8.

Onyewotu, L.O.Z., M.A. Ogigirigi \& C.J. Stigter, 1994.

A study of competitive effects between a Eucalyptus camaldulensis shelterbelt and an adjacent millet

(Pennisetum typhoides) crop.

Agriculture, Ecosystems and Environment 51: 281-286.

Sivakumar, M.V.K., J.S. Wallace, C. Renard \& C. Giroux (Eds.), 1991.

Soil water balance in the Sudano-Sahelian Zone.

IAHS Publication No. 199, International Association of Hydrological Sciences, Wallingford, 628 pp.

Stewart, J.I., 1991.

Principles and performance of response farming.

In: R.C. Muchow \& J.A. Bellamy (Eds.), Climatic Risk in Crop Production: Models and Management for the Semi-arid Tropics and Subtropics. CAB International, Wallingford, pp. 361-382.

Stigter, C.J. \& A. Weiss, 1986.

In quest of tropical micrometeorology for on-farm weather advisories. Guest Editorial.

Agricultural and Forest Meteorology 36: 289-296.

Teme, B., H. Breman \& K. Sissoko, 1996.

Intensification agricole au Sahel: mythe ou réalité?

Projet Production Soudano-Sahelienne (PSS), PSS, Wageningen, 28 pp. + Annexes 


\section{Acknowledgements}

This work was carried out in the context of the project "Traditional Techniques of Microclimate Improvement (TTMI)" (1985-1998), funded by DGIS/DST/SO, Ministry of Foreign Affairs, The Netherlands. Parts of the contents were used in an invited lecture given by Dr. Onyewotu and Prof. Stigter at the African Centre for Meteorological Applications for Development (ACMAD), in Niamey, Niger, on July 11th, 1996.

(C) NJAS 584, 1998 - Comments to: J.J.Neetson@ AB.DLO.NL 